\title{
Business English Translation Strategies in the Perspective of Skopos: In the Case of Advertisement Translation
}

\author{
Lili Zhang \\ Beijing Wuzi University, Beijing, China \\ Email: mywritingclass@163.com
}

Received 30 April 2016; accepted 17 June 2016; published 21 June 2016

Copyright (C) 2016 by author and Scientific Research Publishing Inc. This work is licensed under the Creative Commons Attribution International License (CC BY). http://creativecommons.org/licenses/by/4.0/ c) (i) Open Access

\begin{abstract}
Skopos theory for a long time remains the core of Functional School of translation. The major principle of Skopos theory is that translation should be processed from the perspective of the intended audiences. Its major theory structure makes it as the guiding principle of business English translation which requires communicative and social textual equivalence. Based on the analysis of Skopos theory and business English translation features, this paper focuses on developing business English translation strategies, particularly in the case of advertisement translation. It aims to play a positive role in promoting the research and practice of business English translation.
\end{abstract}

\section{Keywords}

Skopos Theory, Business English Translation, Advertisement Translation, Strategies

\section{Introduction: Skopos Theory in Translation}

The Skopos theory was put forward by Hans J. Vemeer and developed in Germany in the late 1970s. It is one of important functional approaches to translation. The theoretical orientation was directed to a more functionally and socio-culturally defined concept of translation. The word "Skopos” was from Greek meaning purpose or aim. The theory elaborates on translation as a process with an aim or purpose, and on the target readers or audience of the text. According to the theory, to translate means to develop a target text in a target setting for a target purpose in target situations. In Skopos theory, the source is an "offer of information”, which the translator turns into an "offer of information” for the target audience (Vermeer, 2001). Consequently, the choice of translation strategies is determined by the purpose of the translation text, in order to produce a better functional text. In the frame sense of this theory, one of the most important factors defining the purpose of a translation is the 
expected receiver or reader of the target text. The theory focuses above all on the purpose of the translation, which determines the translation methods and strategies that are to be employed in order to produce a functionally adequate result (Vermeer, 2001).

Paul Kussmaul writes about this theory: "...the functional approach has a great affinity with Skopos theory..." These factors determine whether the function of the source text or passages in the source text can be preserved or have to be modified or even changed (Vermeer, 1989). According to Hans J Vermeer and following translation theory experts, there are three main rules of the Skopos theory: skopos rule which means that a translation action is justified by its purposes, coherence rule holding that the target text must be interpretable as coherent with the target receiver's settings and circumstances, and fidelity rule which states that there must be coherence between the translated version and the source text (Vermeer, 1989).

\section{Business English Translation and Skopos Theory}

Business English translation is a special category of translation with distinctive features and requirements. With the functional rules and principles, the Skopos theory becomes the effective guidance of business English translation.

\subsection{Special Features of Business English Translation}

Business English is an important branch of ESP (English for Special Purposes), which is composed of all English language texts applied in business fields. It basically presents informative texts and communicative texts. In essence, business English translation is supposed to transfer business texts from the original language to the target language, and it is a process of cross-cultural business communication. Due to the specific characteristics of business activities, business English translation has special features of its own. Terminology, accuracy and formality, acronyms and derivatives all pose a challenge to business English translators who are required to get some basic gist of business expertise knowledge and practical translation strategies and skills (Liu, X. F., 2012).

\subsection{Coordination between Skopos and Business English Translation}

Skopos theory takes seriously factors which have always been stressed in action theory (Nord, 2001). In the translation of scientific and academic papers, instructions for use, tourist guides, contracts, etc., the contextual factors surrounding the translation cannot be ignored. These factors include the culture of the intended readers of the target text and of the client who has commissioned it, and, in particular, the function which the text is to perform in that culture for those readers. Skopos theory is directly oriented towards this function. Therefore, the utmost goal of business English translation, that is, the functional equivalence of business effect, can be fully reached in the perspective of Skopos. The Skopos theory can be considered as the theoretical base of business English translation. The three rules of the Skopos theory can be fully exhibited in the real business translation practice. The skopos rule acts as the action guidance of business English translator; coherence rule guarantees the target text is translated in such a way that it is coherent for the target text receivers; fidelity rule realizes the relationship with the corresponding source text. In general, a coordinative point can be found between Skopos theory and business English translation: reader-centered or target-culture-oriented.

\section{Advertisement Translation Strategies in the Perspective of Skopos}

Advertisement is a prominent form of business promotion. A company resort to advertisements to inform, to persuade and to remind customers of their products and services. The intensifying international business brought about a growing need of cross-cultural communication and thus of translation. In these cases, advertisement translation becomes more and more widespread and popular. Since it is important to meet the expectation of the target language consumers as to what message the advertisement delivers, the evaluation of advertisement translation relies completely on the target audiences' responses. In order to get the intended purpose of buying action from target consumers, Skopos, as a specific functional translation theory, offers clear direction and resultful strategies to advertisement translation.

\subsection{Gaining Equivalence of Business Effect}

As the basic concept of standards, Dynamic Message Equivalence has been served as the core criterion of business 
English translation. It includes: equivalence of semantic message of source language and target language; equivalence of stylistic message of source language and target language; equivalence of cultural message of source language and target language; and equivalence of business effect of source language and target language (Weng, 2013). The expected business effect of advertisement is to promote product and service, wake up customer's product awareness, and thus stimulate the sales. To this end, the advertisement translation is supposed to be informative, impressive, persuasive, and arouse customer's interest and purchasing desire. Language choice and polishing appear to be very important in this process. Gaining this promotional business effect plays the key role in the success of advertisement translation.

\subsection{Being Cross-Cultural and Target-Culture-Oriented}

Any translation is inseparable from the culture. Different cultural background, customs, etc cause a huge gap in Western and Chinese advertisement expression. In translation, to realize the ideal textual conversion from source language to target language, translators must have cross-cultural mindset and be target-culture-oriented. Due to the cultural barriers, an advertisement, when translated literally, may not be as successful as the original one, even some misunderstandings and troubles could arise. That is because when an advertisement is designed, the advertiser has to be sure that the original audience can comprehend and accept it in the source language and background. But when the situation varies, the persuasive effect in source culture may not be produced in the target culture (Liu, Y. M., 2012). To avoid this predicament, advertisement translation must be target-culture oriented. If the translator takes no note to the target language and culture, the translation may seem odd to the target audience and cannot attract their attention and thus fail to promote sales. The translation turns to be a failure. Therefore, the best strategies in this respect is getting familiar with the target culture, holding a cross-cultural mindset and making the translation of advertisement adapted to the target language style and cultural standards. Only in this way can the translation realize the rules of Skopos in the advertisement.

\subsection{Catering to Customer's Needs}

Advertising is a form of marketing activity which is dedicated to satisfying customer's needs. Knowing and catering to customer's needs require advertisement translation to be reader-centered and customer-tailored. Since the basic function of advertisements is passing on information and by praising certain brands, finally promoting the products or services, a good translation of advertisement is the one that successfully achieves this purpose, that is, functionally catering to the customers' needs. In practice, when recommending those to foreign readers, we should pay attention to their expectations and comprehensibility by choosing a proper expression similar in sound to the original name and at the same time indicating a good sense (about the nature, usage or advantages, etc.), the target text creates a favorable and happy business atmosphere and is easy to remember (Liu, Y. M., 2012).

\section{Conclusion}

Although it is not perfect, Skopos theory is a great breakthrough in the development of translation theories. It put emphasis on translation which is considered as an activity with an aim or purpose at the target readers or audiences. It underscores the communicative purpose of the translation, which requires business English translators have a clear understanding of the communicative function of the business activities. With the deepening of globalization, business English is more and more widely used in the cross-cultural and business-like communications. The application of the Skopos theory in the business English translation breaks many barriers of malcommunication in business and solves many language problems in the way of trans-national business activities. Advertisement translation is a typical case of this. In the perspective of Skopos, advertisement translators are supposed to develop a set of translation strategies, i.e. to realize equivalence of business effect; to be cross-cultural and target-culture-oriented; to cater to customer's needs. It is believed that the Skopos theory acts as the inherent guiding principle for business English translation, and the translator can employ it as the guidance in this process of translation strategy development.

\section{Fund}

This article is funded by 2015BWU Youth Fund Project "Research and Practice of Business English Translation 
Based on Skopos Theory”.

\section{References}

Liu, X. F. (2012). Discussion on Business English Translation Guided by Skopos-Theory. Journal of Guangxi Vocational and Technical College, No. 5, 96-100.

Liu, Y. M. (2012). Business English Translation in the Perspective of Skopos. Shijiazhuang: Hebei Normal University.

Nord, C. (2001). Translating as a Purposeful Activity: Functionalist Approaches Explained. Shanghai: Shanghai Foreign Language Education Press.

Vermeer, H. J. (1989). Skopos and Commission in Translational Action. Helsinki: Oy Finn Lectura Ab.

Vermeer, H. J. (2001). A Framework for a General Theory of Translation. Shanghai: Shanghai Foreign Language Education Press.

Weng, F. X. (2013). An Approach to the 4Es Translation Criterion of Business English. Shanghai Journal of Translators, No. $1,34-38$

\section{Submit or recommend next manuscript to SCIRP and we will provide best service for you:}

Accepting pre-submission inquiries through Email, Facebook, Linkedin, Twitter, etc A wide selection of journals (inclusive of 9 subjects, more than 200 journals)

Providing a 24-hour high-quality service

User-friendly online submission system

Fair and swift peer-review system

Efficient typesetting and proofreading procedure

Display of the result of downloads and visits, as well as the number of cited articles

Maximum dissemination of your research work

Submit your manuscript at: http://papersubmission.scirp.org/ 